Postpint of Journal of Environmental Management, 264, art. no. 110544 (2020).

DOI: http://doi.org/10.1016/j.jenvman.2020

\title{
SELF-SUSTAINING TREATMENT AS A NOVEL ALTERNATIVE FOR THE STABILIZATION OF ANAEROBIC DIGESTATE
}

\author{
A. Serrano ${ }^{\mathrm{a}, \mathrm{b}}$, H. Wyn ${ }^{\mathrm{a}}$, L. Dupont ${ }^{\mathrm{c}}$, D.K. Villa-Gomez ${ }^{\mathrm{a}}$, L. Yermán ${ }^{\mathrm{a}, *}$
}

a. School of Civil Engineering, The University of Queensland, Brisbane 4072, Australia

b. Instituto de Grasa, Spanish National Research Council (CSIC). Ctra. de Utrera, km. 1, Seville, Spain

c. Département Génie Énergétique et Environnement, INSA, 69100 Villeurbanne, France

*Corresponding author: l.yerman@uq.edu.au

\section{Abstract}

Self-sustaining smouldering combustion (SSS) is a technology based on the flameless oxidation of an organic substrate, and limited by the rate at which oxygen is diffused to the surface of the substrate. This work aims to evaluate the SSS combustion as a treatment process for the stabilization of anaerobic digestate, determining the limits of operational conditions, (moisture content (MC), air flux) that allow for a self-sustaining process. Maximum possible MC was found at $82 \mathrm{wt} \%$ with Darcy air flux of $50 \mathrm{~cm} / \mathrm{s}$. The digestate destruction rate $(\mathrm{kg} /(\mathrm{h} \cdot \mathrm{m} 2)$, and the addition of sand as an inert solid, to enhance the oxygen diffusion, were also investigated. A sand/substrate mass ratio of 1 allowed for SSS at 85 wt\% MC, but decreased the digestate destruction rate. The average composition of the emitted gases showed ca. $25 \% \mathrm{CO}$ and $10 \% \mathrm{H}_{2}$, whereas the analysis of the ashes showed almost complete digestate inertization. 
1 Keywords: anaerobic digestion; ash; moisture content; post-treatment; smouldering

2 combustion

\section{Introduction}

Anaerobic digestion is a global established technology applied for the sustainable management of a wide range of organic waste, such as sewage sludge, municipal solid waste and/or different agro-industrial waste streams (Fermoso et al., 2018; Mehariya et al., 2018). During the process, organic matter is transformed into biogas, mainly composed of methane and carbon dioxide, and a semi-stabilised wet residue called digestate. Whereas the biogas produced has enormous potential as a renewable energy source, many questions about the disposal and valorisation of the digestate remain unanswered (Jimenez et al., 2017; Nkoa, 2014). Digestate management is often overlooked, however, regulatory frameworks already in force and those that are anticipated in future make management of anaerobic digestate mandatory (BIOGAS3, 2016; Logan \& Visvanathan, 2019).

The composition and characteristics of the digestate depends mainly on the feed types and the operating conditions of a specific anaerobic digester (Logan \& Visvanathan, 2019), but is mainly composed by water (up to $95 \mathrm{wt} \%$ ), and a mixture of biodegradable and nonbiodegradable organic matter, microbial biomass and inorganic compounds (EBA, 2015; Kaparaju et al., 2012; Serrano et al., 2014).

The use of digestate, from different organic waste sources, has been proposed as soil amendment (Manyi-Loh et al., 2019; Rauseo et al., 2019). However, this option is still under debate as it also introduces chemical and biological contaminants that may affect soil productivity (Nkoa, 2014; Rauseo et al., 2019). Furthermore, when the anaerobic degradation is not exhausted, digestate contains high amounts of organic matter of undigested feedstock that can potentially generate greenhouse gas emissions (up to $125 \mathrm{~g} \mathrm{CO}_{2}$-eq/kg stored digestate) (Kaparaju et al., 2012; Logan \& Visvanathan, 2019), which can exceed standard 
limits for its application as soil amendment (Peng \& Pivato, 2019). Digestate also concentrates non-biodegradable and more recalcitrant molecules (e.g. lignin and nonhydrolysable lipids) that also requires disposal. For instance, digestate originating from agricultural biomass typically contain unconverted lignocellulose material (Xu et al., 2019), while digestate from the organic fraction of municipal solid waste also may contain plastic, rubber, metal, glass, ceramic and sand (Miezah et al., 2015; Ranieri et al., 2018).

The chemical risk of applying digestate as soil amendment is usually associated with the presence of ammonia (Törnwall et al., 2017), heavy metals (Alburquerque et al., 2012), phytotoxic compounds (Inglett et al., 2009; Logan \& Visvanathan, 2019; Nkoa, 2014) and pathogens, especially in manure and sewage digestates (Coelho et al., 2018; Törnwall et al., 2017). Due to the above-mentioned potential contaminants, soil application of not-stabilized digestate has been reported to produce negative effects on seed germination and plant growth (Kaparaju et al., 2012).

Different post-treatment methods, such as composting, combustion (incineration and pyrolysis) and chemical hydrolysis (e.g. ozonisation or alkaline hydrolysis) have been previously proposed as a management treatment prior to application into soil or to minimize transportation and handling costs (Bustamante et al., 2013; Monfet et al., 2018; Peng \& Pivato, 2019). All these methods display advantages and drawbacks. For instance, composting of digestate, which allows the mineralization of chemical components within the sludge and is relatively easy to operate and low cost, may still involve risks due to the presence of heavy metals and organic contaminants (Monfet et al., 2018; Zhang et al., 2019) as well as high energy costs when aeration is required (Roy et al., 2018; Suffet et al., 2009). The application of combustion and chemical thermohydrolysis processes requires a pretreatment step to reduce the moisture content (MC) of digestates that implies energy and management costs (Monfet et al., 2018; T Lukehurst et al., 2010). Considering these 
disadvantages, it is necessary to assess new management alternatives with minimal energy and cost requirements, but ensuring stability and safety of the end-products from the anaerobic digestion process.

In this context, self-sustaining smouldering (SSS) combustion is a potential alternative for low-cost and on-site management of anaerobic digestate. It involves flameless oxidation of a substrate (fuel), limited by the rate at which the oxygen, or air, (oxidant) is diffused into the reactor (Rashwan et al., 2016). This process allows the operation in a self-sustaining manner (low energy requirements), even at very high MC (75 - $80 \mathrm{wt} \%)$, with end-products leaving as a stabilized ash and combustion gases (Rashwan et al., 2016; Yermán, 2016). The process is a sustainable option, as no dewatering of the digestate would be needed. In addition, the low energy requirements could be supplied by the methane produced during the anaerobic digestion in an integrated treatment system.

Self-sustaining smouldering has been applied as a treatment process for organic pollutants such as coal tar (Pironi et al., 2009), crude oil (Xia et al., 2003), sewage sludge (Rashwan et al., 2016) and faeces (Yermán et al., 2016). The optimal SSS conditions can be assessed based mainly on the waste treatment (destruction) rate, which in turn depend on different interrelated parameters (Yermán, 2016). In general, the most critical parameters to be defined for the treatment of a substrate are the air flux through the reactor, nature of the fuel/waste (i.e. moisture content, enthalpy of combustion, particle size), and whether it is required to add an inert porous material as bulk agent (Zanoni et al., 2019). Fabris et al. (2017) described that an increment in the substrate destruction rate during the SSS can be achieved by increasing the Darcy air flow. However, this increase can also result in a drop of the smouldering temperature due to the effect of heat transfer between the combustion gases and the substrate in the reactor (Yermán, 2016). These differences were not only linked to MC, which acts as 
an energy sink during the SSS process, but also to the inert content of the substrates, porosity, flow permeability and organic composition (Huang et al., 2015; Rein, 2013).

The present work aims to evaluate the key operational thresholds (Darcy air low and sand/substrate ratio) and MC limits where SSS can be applied as a sustainable treatment technique for the stabilization of anaerobic digestates. The end-products of smouldering were also characterised for its potential impact and management.

\section{Materials and methods}

\subsection{Materials}

Digestate samples were obtained from a $20 \mathrm{~L}$ lab-scale anaerobic digestion reactor operating in batch mode at mesophilic conditions and treating wasted strawberry. At the end of the batch experiment (20 days of operation), the digestate was stored in closed buckets and kept refrigerated at $4{ }^{\circ} \mathrm{C}$ before use.

Coco coir from exhaust hydroponic crops was selected as support material and fuel for the SSS experiments. It consists of short fibres, chips, and pith. It was supplied by Sunny Ridge ${ }^{\circledR}$ farm, located in Caboolture Region, QLD, Australia. Samples were stored in closed containers in a cool and dry environment to avoid variations in composition or MC. Filter Sand with a particle size between 0.30 and $1.80 \mathrm{~mm}$ (mean size of $0.90 \mathrm{~mm}$, RIVERSANDS Pty Ltd) was used in the experiments.

The composition of the substrates including MC, volatile solids, fixed carbon, ashes content, higher heating value (HHV), and elemental analysis is presented in Table 1. According to the elemental analysis of both substrates, the digestate presented higher proportions of minority elements than the coir, although the carbon content in both substrates was similar, i.e. $43.5 \pm 0.3 \%$ and $45.8 \pm 0.8 \%$ for digestate and coco coir, respectively. 


\subsection{Experimental set-up}

$60.5 \mathrm{~mm}$ internal diameter) were used to carry out the SSS combustion experiments (Figure

1) (more details are available in Yermán et al. (2016)). The base of the reactor housed a

heating element (Incoloy-sheathed, $2.2 \times 4.2 \mathrm{~mm}$ cross-section), and an air diffuser. The base

was filled with a layer of coarse gravel, fine gravel, and then sand to provide uniform air flux.

The heater was covered with a $20 \mathrm{~mm}$ layer of sand. The reactor column was clamped on top of the base to avoid air leaks. A vertical thermocouple line (11 thermocouples) was placed in the central axis of the column to monitor and record temperature as a function of the time and position (height in reactor) during the SSS experiments. The first thermocouple (closest to the heater) was located at $20 \mathrm{~mm}$ from the heater. The following four thermocouples were spaced at $10 \mathrm{~mm}$ from each other (30, 40, 50 and $60 \mathrm{~mm}$ from the heater), while the rest are uniformly spaced at $100 \mathrm{~mm}$ (up to $600 \mathrm{~mm}$ ). In this way, a higher temperature resolution is obtained in the portion of waste bed close to the heater (bottom of the reactor).

\subsection{Experimental design}

The experiments were designed to assess the limits of MC (higher limit) and Darcy air flux (lower limit) where SSS is possible. For this purpose, eighteen experiments were conducted (Table 2). Six additional experiments were performed to evaluate the impact of the addition of sand to the process (Table 2). In particular, it was tested whether the operative limits (MC and air flux) already found could be extended with the addition of sand. Table 2 summarises the conditions for all the experiments carried out, including MC, Darcy air flux, and the sand-to-substrate mass ratio in wet basis (considering the mass of substrate as the sum of the masses of coir and digestate). In each case, the desired MC was adjusted by mixing different ratios of coir and digestate. All the experiments were carried out at least twice to ensure repeatability. 
For each experiment, the mixture of substrates was loaded into the reactor from the

top, and $10 \mathrm{~mm}$ layer of clean sand was placed on top of the bed of waste, to act as thermal insulation (Pironi et al., 2009). Following, the heating element is turned on to initiate heating. Once the thermocouple at $20 \mathrm{~mm}$ above the heater reaches $250^{\circ} \mathrm{C}$, the heater is turned off, and air flux is initiated by means of a mass flow controller (Cole Parmer 32907-75). The processes were considered SSS when the whole substrate mixture was converted into ashes.

The conditions where the process was not totally converted into ashes where defined as nonself-sustained smouldering (NSSS), whereas the conditions where the process occurs only sometimes where defined as borderline-self-sustained smouldering (BSSS).

\subsection{Analytical methods}

Both digestate and coco coir were characterized by proximate and ultimate analyses, bomb calorimetry, thermogravimetric analysis (TGA) and differential scanning calorimetry (DSC). MC and volatile solids of the samples was determined following the ASTM E871-82 and ASTM E872-82 standards, respectively. Ash content was determined following the ASTM E102-84 standard. Fixed carbon was then calculated by difference. HHV was determined with a Parr 1341 bomb calorimeter. The TGA and DSC experiments were carried out using a Perkin Elmer STA6000 with a heating rate of $20^{\circ} \mathrm{C} / \mathrm{min}$ up to $800{ }^{\circ} \mathrm{C}$ under air atmosphere with a gas flow rate of $20 \mathrm{~mL} / \mathrm{min}$.

Elemental analysis of the substrates and ashes obtained after the combustion was carried out with a LECO TruSpec analyser for content of C and N. Varian Vista Pro ICPOES instrument for the quantification of $\mathrm{Al}, \mathrm{As}, \mathrm{B}, \mathrm{Ba}, \mathrm{Ca}, \mathrm{Cd}, \mathrm{Co}, \mathrm{Cr}, \mathrm{Cu}, \mathrm{Fe}, \mathrm{K}, \mathrm{Mg}, \mathrm{Mn}$, $\mathrm{Mo}, \mathrm{Na}, \mathrm{Ni}, \mathrm{P}, \mathrm{Pb}, \mathrm{S}, \mathrm{Se}$, and $\mathrm{Zn}$. Prior to the determination, samples were dried in an oven at $105{ }^{\circ} \mathrm{C}$ and grounded using a Retsch SM200 and Retsch ZM200 for uniformity. Product gases were sampled with a syringe that was placed above the waste bed (inside the reactor, at $15 \mathrm{~cm}$ from the top). Once sampled, the gases were stored in airtight 
1 glass vials (Labco Exetainers $12 \mathrm{~mL}$ ), which were stored in cool conditions ready for

2 analysis. Gas composition analysis was conducted by means of gas chromatography

3 (PerkinElmer Clarus 590 GC), coupled with TCD and FID to measure concentrations of $\mathrm{H}_{2}$,

$4 \mathrm{CO}_{2}, \mathrm{O}_{2}, \mathrm{~N}_{2}, \mathrm{CH}_{4}$, and $\mathrm{CO}$.

5

6 3. Results and Discussion

$7 \quad 3.1$ Thermochemical characterisation of the substrates

The TG and DSC curves for the digestate as a function of time is shown in Figure 2a. A continuous mass loss was observed from $100{ }^{\circ} \mathrm{C}$ until ca. $720{ }^{\circ} \mathrm{C}$ (TGA curve, Figure 2a), while the heat energy curve showed a broad exothermic peak at $c a .620{ }^{\circ} \mathrm{C}$ within the range of 500 to $720{ }^{\circ} \mathrm{C}$ (DSC curve, Figure 2a). This broad exothermic peak in the DSC curve presents two shoulder peaks 580 and $700{ }^{\circ} \mathrm{C}$ ), which indicates that there are at least three main different type of group compounds oxidized at different temperatures $(580,620$ and 700 ${ }^{\circ} \mathrm{C}$ ), where full oxidization of the digestate was obtained at $720^{\circ} \mathrm{C}$.

A continuous mass loss from the start of the experiment at $30^{\circ} \mathrm{C}$ till the end at $540{ }^{\circ} \mathrm{C}$ for dried coco coir was observed C (Figure 2b). The DSC curve of coco coir showed two exothermic peaks. The first is between 240 and $400{ }^{\circ} \mathrm{C}$, and the second between 400 and 540 ${ }^{\circ} \mathrm{C}$ (Figures $2 \mathrm{a}$ and $2 \mathrm{~b}$ ). The small peak at $100{ }^{\circ} \mathrm{C}$ corresponds to the typical water mass loss, due to water adsorbed from the environment just before conducting the experiment.

The energy released from the coir combustion at temperatures higher than $240{ }^{\circ} \mathrm{C}$ confirms that the use of coco coir can help to reach the required conditions for the selfsustaining oxidation of the digestate, i.e. $500{ }^{\circ} \mathrm{C}$ or above. Therefore, a fixed ignition temperature of $250{ }^{\circ} \mathrm{C}$, slightly higher than the combustion temperature of the coir, was selected as it would allow obtaining higher energy efficiencies during the SSS start-up (Yermán, 2016). 
$\mathrm{kJ} / \mathrm{g}$ and $19.44 \pm 0.23 \mathrm{~kJ} / \mathrm{g}$, respectively Table 1) and within the reported for different woody

biomass, e.g. $23.3 \mathrm{~kJ} / \mathrm{g}$ for wood (Bagheri et al., 2020), $25.56 \mathrm{~kJ} / \mathrm{g}$ for olive pomace hydrochar, 18.06 kJ/g for wood sawdust (Başakçılardan Kabakcı \& Baran, 2019), or 19.14 kJ/g for eucalyptus shavings (Protásio et al., 2013).

\subsection{Determination of the operational parameters for a self-sustaining smouldering combustion}

The influence of MC, through varying the digestate/coir ratio, and the Darcy air flux were evaluated to determine the threshold conditions to carry out a SSS process (Figure 3 and Table 3). The increment in the Darcy air flux from 10 to $50 \mathrm{~cm} / \mathrm{s}$ allowed SSS at a higher MC (Figure 3). The maximum allowable MC was $82 \mathrm{wt} \%$, which corresponded to a digestate/coir ratio of 0.92 (in wet mass basis), requiring a Darcy air flux of $50 \mathrm{~cm} / \mathrm{s}$. A MC higher than this will quench the reaction as the energy generated during the combustion could not overcome the energy needed to evaporate the moisture in the material. It is important to highlight that the moisture content of the waste has no effects on the smouldering kinetics, as the combustion takes place in completely dried waste. This was previously reported by Yermán (2016) and Yermán et al. (2017). The maximum recorded MC was slightly higher than the maximum MC reported by Rashwan et al. (2016) for SSS of biosolids (80wt\%), or by Yermán et al. (2015) for SSS of faeces (75 wt\%). The difference in these maximum MC could be attributed to the higher HHV of the digestate, i.e. $20.36 \mathrm{~kJ} / \mathrm{g}$ (Table 1) vs $17.5 \mathrm{~kJ} / \mathrm{g}$ for faeces and $17.2 \mathrm{~kJ} / \mathrm{g}$ to $18.1 \mathrm{~kJ} / \mathrm{g}$ for biosolids. The time required for the completion of the SSS at the studied conditions varied from 20 up to $45 \mathrm{~min}$, and are strongly dependent on the airflow rate (Yermán et al., 2016) (data not shown).

As an indicator of the behaviour of the processes, the experiments where SSS conditions were maintained presented maximum temperature $\left(T_{\max }\right)$ values higher than 800 
${ }^{\circ} \mathrm{C}$, except for experiments at MC $75 \%$ and a Darcy air flux of $30 \mathrm{~cm} / \mathrm{s}$ (Table 3). On the other hand, most of the non-SSS experiments (except experiment 18) presented $\mathrm{T}_{\max }$ values below $770{ }^{\circ} \mathrm{C}$. A low $\mathrm{T}_{\max }$ usually implies limited transference of energy from the combustion gases to the substrate during the SSS process, releasing the gases at high temperature and, then, resulting in a non-sustainable smouldering due to the lack of drying of the substrate in the reactor (Yermán, 2016). As expected (Switzer et al., 2014; Yermán et al., 2017), a linear relationship between digestate destruction rate (DDR) and Darcy air flux was observed in this study, where higher Darcy air fluxes resulted in higher DDR. For example, the increment of the Darcy air flux from 35 to $40 \mathrm{~cm} / \mathrm{s}$, at a MC of $80 \%$, increased DDR by $11.7 \%$ (Table 3). However, a higher Darcy air flux is usually not desirable, as it means higher energy consumption.

\subsection{Effect of sand addition}

After defining the required conditions for the SSS of digestate and coir, the addition of sand was proposed as a way to extend the SSS parameters boundaries (MC and air flux).

Table 4 summarised the combustion parameters obtained for the combustion of two different mixtures of digestate and coir at different sand/substrate ratio. For a MC of $75 \mathrm{wt} \%$, the addition of different ratios of sand was carried out to reduce the required Darcy air flux determined in Section 3.2. As can be seen, the addition of sand in a sand/substrate ratio of 0.5 was enough to reduce the required Darcy air flux from 15 to $5 \mathrm{~cm} / \mathrm{s}$ (Tables 3 and 4). The combustion at a sand/substrate ratio of 0.5 and $5 \mathrm{~cm} / \mathrm{s}$ allowed the maintaining of the digestate destruction rate in comparison with the operation without sand addition and $15 \mathrm{~cm} / \mathrm{s}$ (Tables 3 and 4). The addition of sand also resulted in a marked increment of $\mathrm{T}_{\max }$ as compared to the operation without the addition of sand, reaching $\mathrm{T}_{\max }$ values of up to $1018{ }^{\circ} \mathrm{C}$ (Table 4), except for the sand/substrate ratio of 0.25 and MC of $75 \%$. This may be due to an increment of the porosity due to the addition of sand, which facilitates oxygen transfer, as 
well as the heat transference for drying between the combustion gases and the substrates in the reactor (Pironi et al., 2009).

The addition of sand for a sand/substrate ratio of 1 allowed SSS at a MC of $85 \%$, resulting in a DDR of up to $48.1 \mathrm{~kg} /\left(\mathrm{h} \cdot \mathrm{m}^{2}\right.$ ) (Table 4). Despite that the sand has been identified as a good inert matrix for SSS, as it can enhance the thermal properties of the medium, such as thermal conductivity and capacity (Pironi et al., 2009; Rashwan et al., 2016; Yermán et al., 2015), it did not sufficiently reduce the energy requirement of the process. This is because the presence of sand not only diminishes the amount of water per unit volume, which decreases the energy required to evaporate it; but also it diminishes the fuel mass per unit volume. In addition, more energy is required to heat the added sand. Therefore, the use of sand for SSS of digestates is only recommended when the MC of the digestate is above $85 \mathrm{wt} \%$, while below this value, its application is unnecessary.

\subsection{Combustion gas analysis}

The composition of the combustion gas products was monitored throughout the SSS process. The combustion gas composition remained constant during the combustion time for most of the components, although some punctual variations in the $\mathrm{CO}_{2} / \mathrm{CO}$ ratio were observed (see Figure S1 in supplementary material). Figure 4 shows the average concentration values of the combustion gas composition. As can be seen, $\mathrm{CO}_{2}$ was the main component in the combustion gas products regardless of the SSS operational conditions, varying in a range from 60 to $70 \%$. $\mathrm{CO}$ and $\mathrm{H}_{2}$ in the combustion gas products were present in percentages around 25 and $10 \%$, respectively. Since the quality of the effluent gas is not comparable to one obtained during pyrolysis for biogas upgrading (Haryanto et al., 2009; Wang et al., 2006) it could be circulated to the anaerobic digestion process as it can act as substrates of hydrogenotrophic archaea to produce methane (Fabbri \& Torri, 2016), which might deliver additional biomethane. This kind of energetic integration has similarly been 
proposed for anaerobic digestion and pyrolysis (Fabbri \& Torri, 2016; Feng \& Lin, 2017;

2 Opatokun et al., 2015). However, further research should be done to monitor the release of nitrogen and sulphide oxides, as well as other pollutants as dioxins, during SSS.

\subsection{Characterization of the residual ashes}

According to the mass loss calculated in the experiments (Figure 5), incineration up to $800{ }^{\circ} \mathrm{C}$ of the ashes only resulted in a mass reduction of around $6 \%$, indicating that almost all the organic matter in the digestate was burnt during the SSS process. This implies a reduction in cost for transporting and handling in comparison with the wet digestates, which in Australia accounts for $\$ 332$ per tonne of waste (Marsden Jacob Associates, 2014). The remaining ash contained high concentrations of nutrients, such as $\mathrm{K}(107 \pm 1 \mathrm{mg} / \mathrm{kg}), \mathrm{P}(58.2$ $\pm 0.8 \mathrm{mg} / \mathrm{kg})$ and $\mathrm{Mg}(30.3 \pm 0.1 \mathrm{mg} / \mathrm{kg})$ (Table 5), thus opening the possibility for the application as a soil amendment (Ukwattage et al., 2013). The concentration of heavy metals in the ashes was lower than the described as limit in the US and European legislations on heavy metals and organic compounds from wastes used as organic fertilisers (see supplementary material, Table S1). However, it is worth to note that the concentration of heavy metals in the SSS ashes will be strongly dependant on the anaerobic digestion feedstock and could be a challenge in the case of digestates from sewage sludge or manure slurries (Jin \& Chang, 2011; Tytła, 2019). Nevertheless, metals contained in ashes from full combustion are mainly as oxides (Ukwattage et al., 2013; Wielinski et al., 2019), which in some cases are more stable forms and less toxic than the organically bound species reported in digestates (Dragicevic et al., 2018).

The remaining ashes can be applied as soil amendment but also as construction material in the elaboration of building material, where combustion ashes have been previously used (Leiva et al., 2016). Therefore, SSS can be considered a promising post-treatment technology for anaerobic digestate allowing total inertization of the waste in the form of ashes with 
multiple end uses, working at high MC and without high energy costs. However, final-use

2 alternatives should be carefully studied to evaluate their technical adequacy and environmental sustainability.

4

5 4. Conclusions

6 Self-sustaining smouldering was able to treat up to $64.4 \mathrm{~kg}$ of wet digestate $/\left(\mathrm{h} \cdot \mathrm{m}^{2}\right)$ at a $7 \mathrm{MC}$ of $82 \mathrm{wt} \%$, which corresponded to a Darcy air flux of $50 \mathrm{~cm} / \mathrm{s}$. The addition of sand for a sand/substrate mass ratio of $1 \mathrm{~g} / \mathrm{g}$ proved to be effective in extending the maximum MC to 85

9 wt $\%$.. Almost total destruction of the organic matter from the digestate was achieved; leaving 10 inert ashes, as the high temperatures of the process ensure the elimination of possible pathogens. This study showed SSS as a low energy-intensive technology option for stabilizing the anaerobic digestate, even at high moisture content. This has the potential to enhance the sustainability of the anaerobic processes by removing the environmental risks associated with the digestate without jeopardizing the energy balance.

\section{Acknowledges}

UQECR1945969 and UQECR1946429.

\section{References}

Alburquerque, J.A., de la Fuente, C., Ferrer-Costa, A., Carrasco, L., Cegarra, J., Abad, M., Bernal, M.P. 2012. Assessment of the fertiliser potential of digestates from farm and agroindustrial residues. Biomass Bioenerg. 40, 181-189. 
Bagheri, M., Esfilar, R., Sina Golchi, M., Kennedy, C.A. 2020. Towards a circular economy: A comprehensive study of higher heat values and emission potential of various municipal solid wastes. Waste Manage. 101, 210-221.

Başakçılardan Kabakcı, S., Baran, S.S. 2019. Hydrothermal carbonization of various lignocellulosics: Fuel characteristics of hydrochars and surface characteristics of activated hydrochars. Waste Manage., 100, 259-268.

BIOGAS3. 2016. European legislative and financial framework for the implementation of small-scale biogas plants in agro-food \& beverage companies. Intelligent Energy Europe.

Bustamante, M.A., Restrepo, A.P., Alburquerque, J.A., Pérez-Murcia, M.D., Paredes, C., Moral, R., Bernal, M.P. 2013. Recycling of anaerobic digestates by composting: effect of the bulking agent used. J. Cleaner Prod. 47, 61-69.

Coelho, J.J., Prieto, M.L., Dowling, S., Hennessy, A., Casey, I., Woodcock, T., Kennedy, N. 2018. Physical-chemical traits, phytotoxicity and pathogen detection in liquid anaerobic digestates. Waste Manage. 78, 8-15.

Dragicevic, I., Eich-Greatorex, S., Sogn, T.A., Horn, S.J., Krogstad, T. 2018. Use of high metal-containing biogas digestates in cereal production - Mobility of chromium and aluminium. J. Environ. Manage. 217, 12-22.

EBA. 2015. Digestate Factsheet. European Biogas Association.

Fabbri, D., Torri, C. 2016. Linking pyrolysis and anaerobic digestion (Py-AD) for the conversion of lignocellulosic biomass. Curr. Opin. Biotechnol. 38, 167-173.

Fabris, I., Cormier, D., Gerhard, J.I., Bartczak, T., Kortschot, M., Torero, J.L., Cheng, Y.L. 2017. Continuous, self-sustaining smouldering destruction of simulated faeces. Fuel, 190, 58-66. 
1 Feng, Q., Lin, Y. 2017. Integrated processes of anaerobic digestion and pyrolysis for higher bioenergy recovery from lignocellulosic biomass: A brief review. Renew. Sustain. Energy Rev. 77, 1272-1287.

Fermoso, F.G., Serrano, A., Alonso-Fariñas, B., Fernández-Bolaños, J., Borja, R., RodríguezGutiérrez, G. 2018. Valuable Compound Extraction, Anaerobic Digestion, and Composting: A Leading Biorefinery Approach for Agricultural Wastes. J.Agri. Food Chem. 66(32), 8451-8468.

Haryanto, A., Fernando, S.D., Pordesimo, L.O., Adhikari, S. 2009. Upgrading of syngas derived from biomass gasification: A thermodynamic analysis. Biomass Bioenerg. 33(5), 882-889.

Huang, X., Rein, G., Chen, H. 2015. Computational smoldering combustion: Predicting the roles of moisture and inert contents in peat wildfires. P. Combust. Inst. 35(3), 26732681.

Inglett, G.E., Rose, D.J., Stevenson, D.G., Chen, D., Biswas, A. 2009. Total Phenolics and Antioxidant Activity of Water and Ethanolic Extracts from Distillers Dried Grains with Solubles With or Without Microwave Irradiation. Cereal Chem. 86(6), 661-664.

Jimenez, J., Lei, H., Steyer, J.P., Houot, S., Patureau, D. 2017. Methane production and fertilizing value of organic waste: Organic matter characterization for a better prediction of valorization pathways. Bioresource Technol. 241, 1012-1021.

Jin, H., Chang, Z. 2011. Distribution of heavy metal contents and chemical fractions in anaerobically digested manure slurry. Appl. Biochem. Biotechnol. 164(3), 268-282.

Kaparaju, P., Rintala, J., Oikari, A. 2012. Agricultural potential of anaerobically digested industrial orange waste with and without aerobic post-treatment. Environmental Technol. 33(1), 85-94. 
1 Leiva, C., Arenas, C., Alonso-Fariñas, B., Vilches, L.F., Peceño, B., Rodriguez-Galán, M., Baena, F. 2016. Characteristics of fired bricks with co-combustion fly ashes. J. Build. Eng. 5, 114-118.

Logan, M., Visvanathan, C. 2019. Management strategies for anaerobic digestate of organic fraction of municipal solid waste: Current status and future prospects. Waste Manage. Res. 37(1_suppl), 27-39.

Manyi-Loh, C.E., Mamphweli, S.N., Meyer, E.L., Okoh, A.I. 2019. Microbial anaerobic digestion: process dynamics and implications from the renewable energy, environmental and agronomy perspectives. Int. J. Environ. Sci. Tech. 16(7), 39133934.

Marsden Jacob Associates. 2014. Estimate of the cost of hazardous waste in Australia. Department of the Environment, Australia.

Mehariya, S., Patel, A.K., Obulisamy, P.K., Punniyakotti, E., Wong, J.W.C. 2018. Codigestion of food waste and sewage sludge for methane production: Current status and perspective. Bioresource Technol. 265, 519-531.

Miezah, K., Obiri-Danso, K., Kádár, Z., Fei-Baffoe, B., Mensah, M.Y. 2015. Municipal solid waste characterization and quantification as a measure towards effective waste management in Ghana. Waste Manage. 46, 15-27.

Monfet, E., Aubry, G., Ramirez, A.A. 2018. Nutrient removal and recovery from digestate: a review of the technology. Biofuels, 9(2), 247-262.

Nkoa, R. 2014. Agricultural benefits and environmental risks of soil fertilization with anaerobic digestates: A review. Agron. Sustain. Dev. 34(2), 473-492.

Opatokun, S.A., Strezov, V., Kan, T. 2015. Product based evaluation of pyrolysis of food waste and its digestate. Energ. 92, 349-354. 
1 Peng, W., Pivato, A. 2019. Sustainable Management of Digestate from the Organic Fraction of Municipal Solid Waste and Food Waste Under the Concepts of Back to Earth Alternatives and Circular Economy. Waste and Biomass Valori. 10(2), 465-481.

Pironi, P., Switzer, C., Rein, G., Fuentes, A., Gerhard, J.I., Torero, J.L. 2009. Small-scale forward smouldering experiments for remediation of coal tar in inert media. P. Combusti. Inst. 32(2), 1957-1964.

Protásio, T.P., Bufalino, L., Tonoli, G.H.D., Guimarães Junior, M.G., Trugilho, P.F., Mendes, L.M. 2013. Brazilian lignocellulosic wastes for bioenergy production: Characterization and comparison with fossil fuels. BioResources, 8(1), 1166-1185.

Ranieri, L., Mossa, G., Pellegrino, R., Digiesi, S. 2018. Energy recovery from the organic fraction of municipal solid waste: A real options-based facility assessment. Sustainability (Switzerland), 10(2).

Rashwan, T.L., Gerhard, J.I., Grant, G.P. 2016. Application of self-sustaining smouldering combustion for the destruction of wastewater biosolids. Waste Manage. 50, 201-212.

Rauseo, J., Barra Caracciolo, A., Ademollo, N., Cardoni, M., Di Lenola, M., Gaze, W.H., Stanton, I.C., Grenni, P., Pescatore, T., Spataro, F., Patrolecco, L. 2019. Dissipation of the antibiotic sulfamethoxazole in a soil amended with anaerobically digested cattle manure. J. Hazard. Mat. 378.

Rein, G. 2013. Smouldering Fires and Natural Fuels. in: Fire Phenomena and the Earth System: An Interdisciplinary Guide to Fire Science, pp. 15-33.

Roy, D., Azais, A., Benkaraache, S., Drogui, P., Dayal Tyagi, R. 2018. Composting leachate: characterization, treatment, and future perspectives. Rev Environ. Sci. Technol. 17(2), 323-349. 
Serrano, A., Siles, J.A., Chica, A.F., Martín, M.A. 2014. Anaerobic co-digestion of sewage sludge and strawberry extrudate under mesophilic conditions. Environ. Technol. 35(23), 2920-2927.

Suffet, I.H., Decottignies, V., Senante, E., Bruchet, A. 2009. Sensory assessment and characterization of odor nuisance emissions during the composting of wastewater biosolids. Water Environ. Res. 81(7), 670-679.

Switzer, C., Pironi, P., Gerhard, J.I., Rein, G., Torero, J.L. 2014. Volumetric scale-up of smouldering remediation of contaminated materials. J. Hazard. Mat. 268, 51-60.

T Lukehurst, C., Frost, P., Seadi, T. 2010. Utilisation of digestate from biogas plants as biofertiliser. IEA Bioenergy.

Törnwall, E., Pettersson, H., Thorin, E., Schwede, S. 2017. Post-treatment of biogas digestate - An evaluation of ammonium recovery, energy use and sanitation. Energy Procedia, 142, 957-963.

Tytra, M. 2019. Assessment of heavy metal pollution and potential ecological risk in sewage sludge from municipal wastewater treatment plant located in the most industrialized region in poland—case study. Int. J. Environ. Res. Public Health 16(13).

Ukwattage, N.L., Ranjith, P.G., Bouazza, M. 2013. The use of coal combustion fly ash as a soil amendment in agricultural lands (with comments on its potential to improve food security and sequester carbon). Fuel, 109, 400-408.

Wang, T., Chang, J., Cui, X., Zhang, Q., Fu, Y. 2006. Reforming of raw fuel gas from biomass gasification to syngas over highly stable nickel-magnesium solid solution catalysts. Fuel Process. Technol. 87(5), 421-428.

Wielinski, J., Gogos, A., Voegelin, A., Müller, C., Morgenroth, E., Kaegi, R. 2019. Transformation of Nanoscale and Ionic $\mathrm{Cu}$ and $\mathrm{Zn}$ during the Incineration of Digested Sewage Sludge (Biosolids). Environ. Sci. Technol. 53(20), 11704-11713. 
1 Xia, T.X., Greaves, M., Turta, A.T., Ayasse, C. 2003. THAI-A 'Short-Distance Displacement' In Situ Combustion Process for the Recovery and Upgrading of Heavy Oil. Chem. Eng. Res. Des. 81(3), 295-304.

Xu, N., Liu, S., Xin, F., Zhou, J., Jia, H., Xu, J., Jiang, M., Dong, W. 2019. Biomethane Production From Lignocellulose: Biomass Recalcitrance and Its Impacts on Anaerobic Digestion. Front. Bioeng. Biotech. 7(191).

Yermán, L. 2016. Self-sustaining Smouldering Combustion as a Waste Treatment Process. in: Developments in Combustion Technology, (Eds.) K.G. Kyprianidis, J. Skvaril, IntechOpen, pp. 143-166.

Yermán, L., Hadden, R.M., Carrascal, J., Fabris, I., Cormier, D., Torero, J.L., Gerhard, J.I., Krajcovic, M., Pironi, P., Cheng, Y.L. 2015. Smouldering combustion as a treatment technology for faeces: Exploring the parameter space. Fuel, 147, 108-116.

Yermán, L., Wall, H., Torero, J., Gerhard, J.I., Cheng, Y.L. 2016. Smoldering Combustion as a Treatment Technology for Feces: Sensitivity to Key Parameters. Combust. Sci. Technol. 188(6), 968-981.

Yermán, L., Wall, H., Torero, J.L. 2017. Experimental investigation on the destruction rates of organic waste with high moisture content by means of self-sustained smoldering combustion. P. Combust. Inst. 36(3), 4419-4426.

Zanoni, M.A.B., Torero, J.L., Gerhard, J.I. 2019. Delineating and explaining the limits of self-sustained smouldering combustion. Combust. Flame, 201, 78-92.

Zhang, J.-N., Yang, L., Zhang, M., Liu, Y.-S., Zhao, J.-L., He, L.-Y., Zhang, Q.-Q., Ying, G.G. 2019. Persistence of androgens, progestogens, and glucocorticoids during commercial animal manure composting process. Sci. Total Environ. 665, 91-99. 


\section{$1 \quad$ Figure Captions}

2 Figure 1. Smouldering combustion reactor setup.

3 Figure 2. Mass (TGA) and heat (DSC) at increasing temperatures for digestate (A) and coco 4 coir (B).

$5 \quad$ Figure 3. Required moisture content (MC) and Darcy air flux allowing for self-sustaining

6 smouldering combustion, where NSSS, non-self-sustained smouldering; SSS, self-sustained 7 smouldering; and BSSS, borderline-self-sustained smouldering.

8 Figure 4. Average product gas distribution during the smouldering process at different

9 operational conditions.

10 Figure 5. Mass (TGA) at increasing temperatures for the ashes obtained after the 11 smouldering process. 
Figure 1.

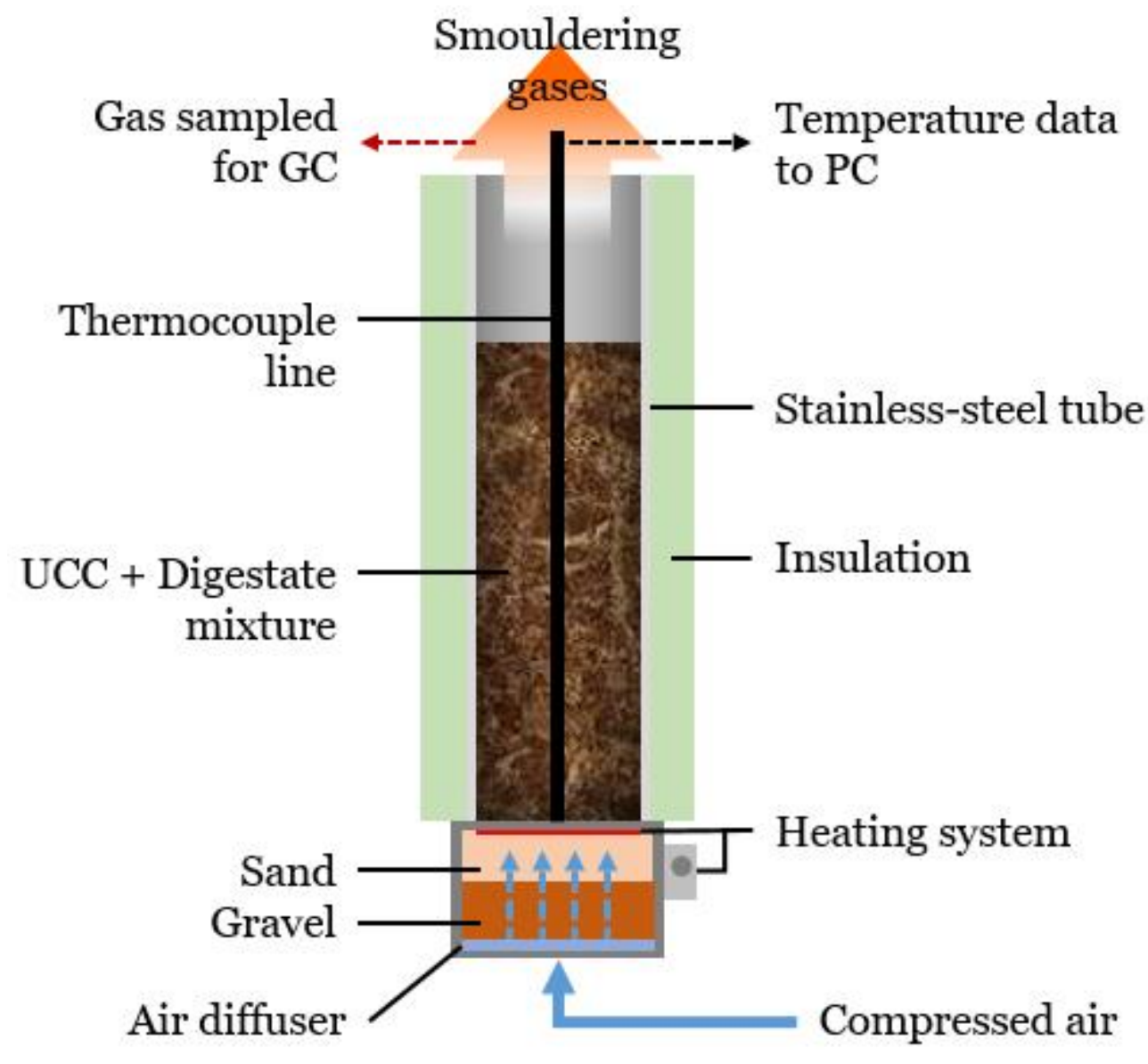


Figure 2

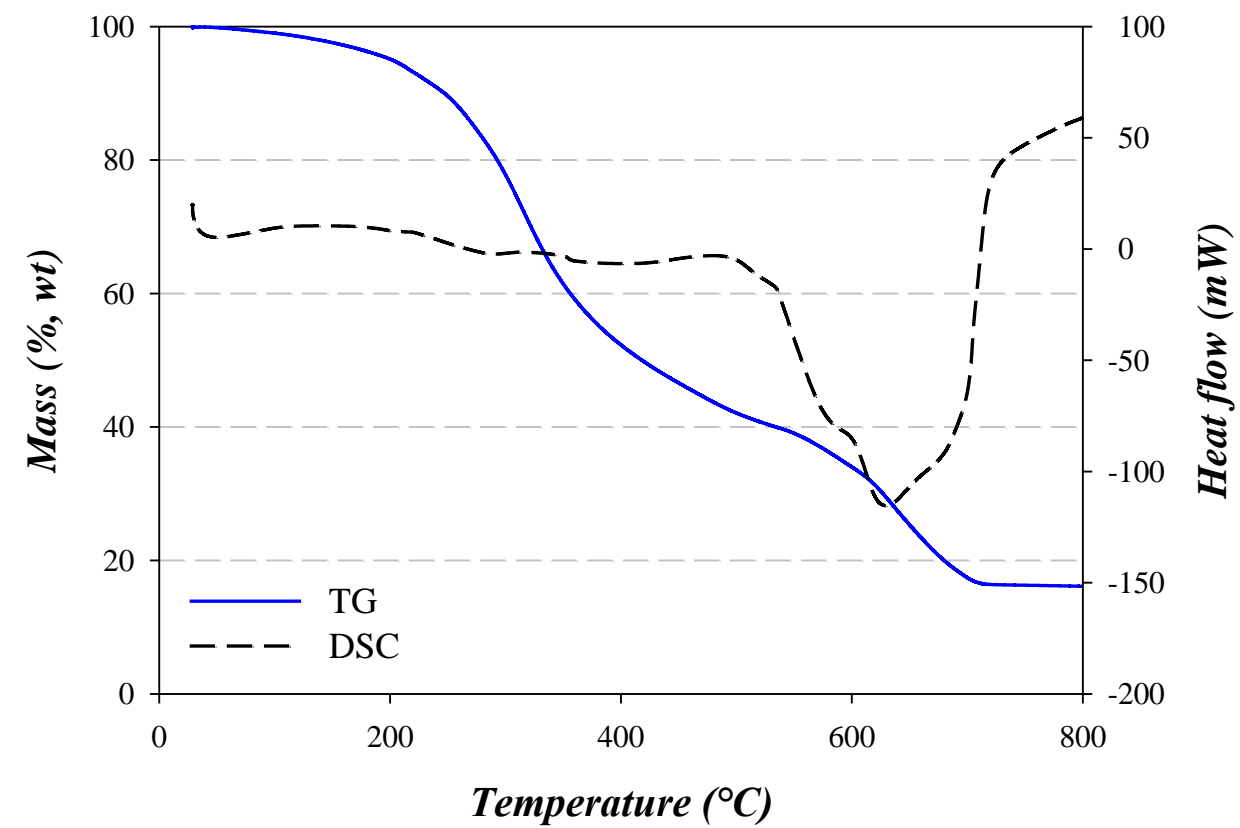

B)

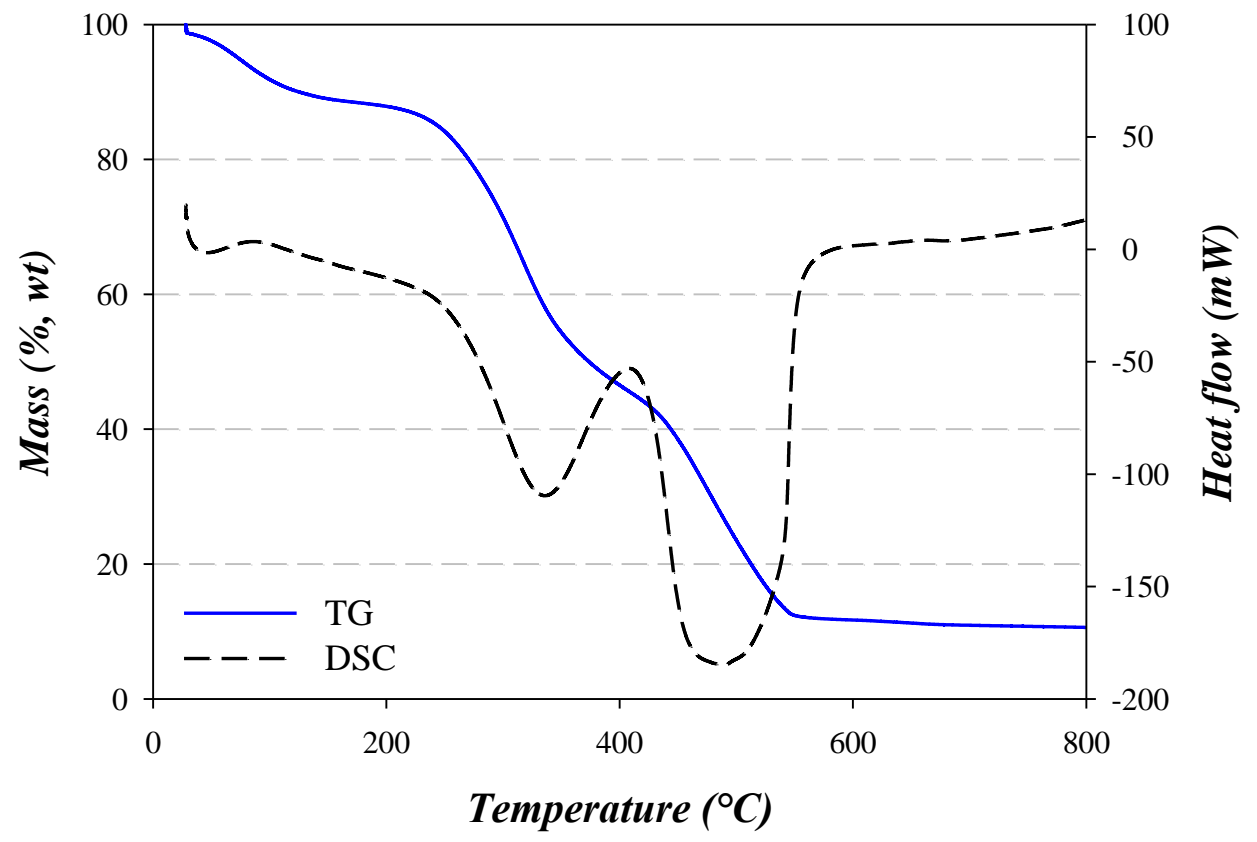


Figure 3.

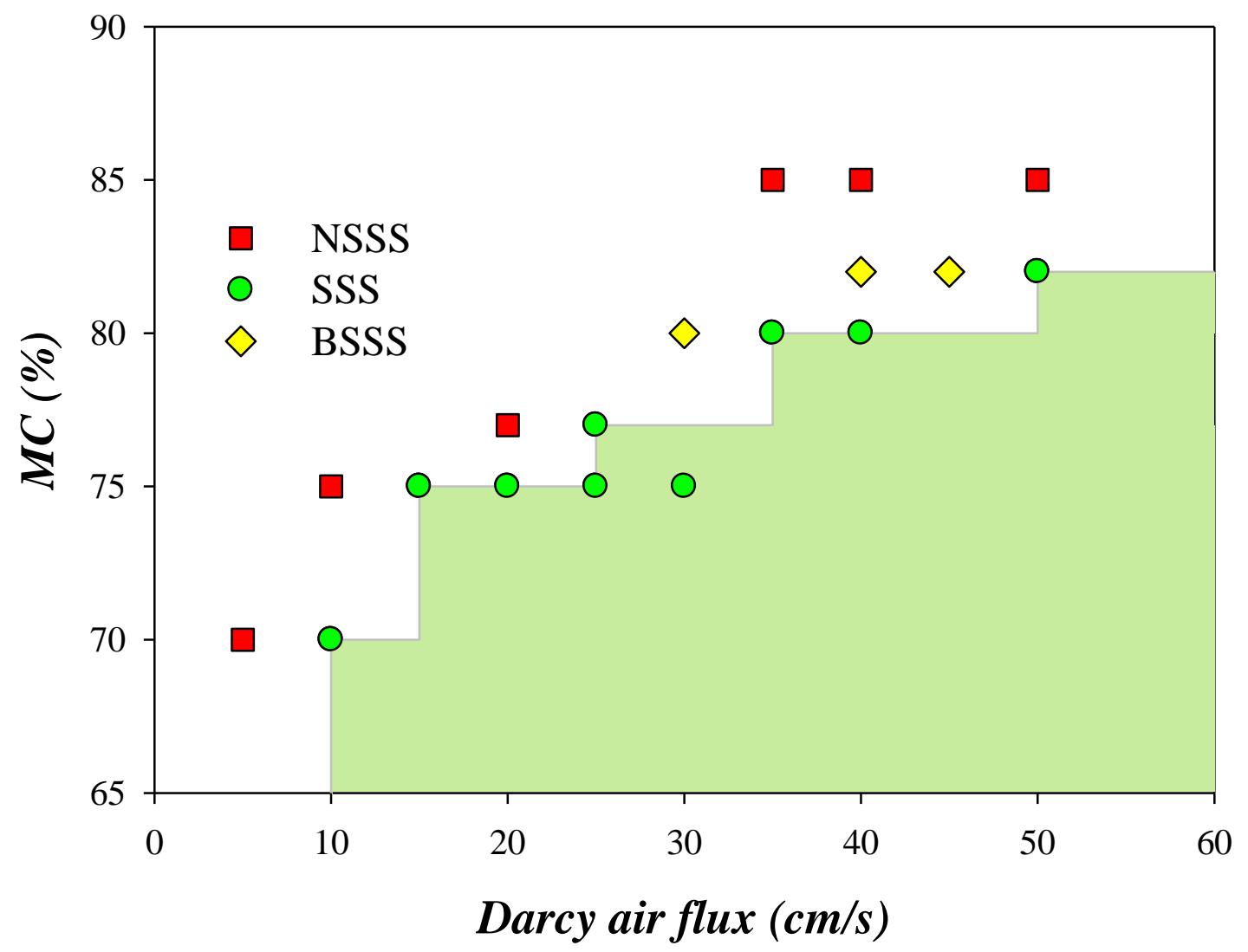

3

4 
$1 \quad$ Figure 4.

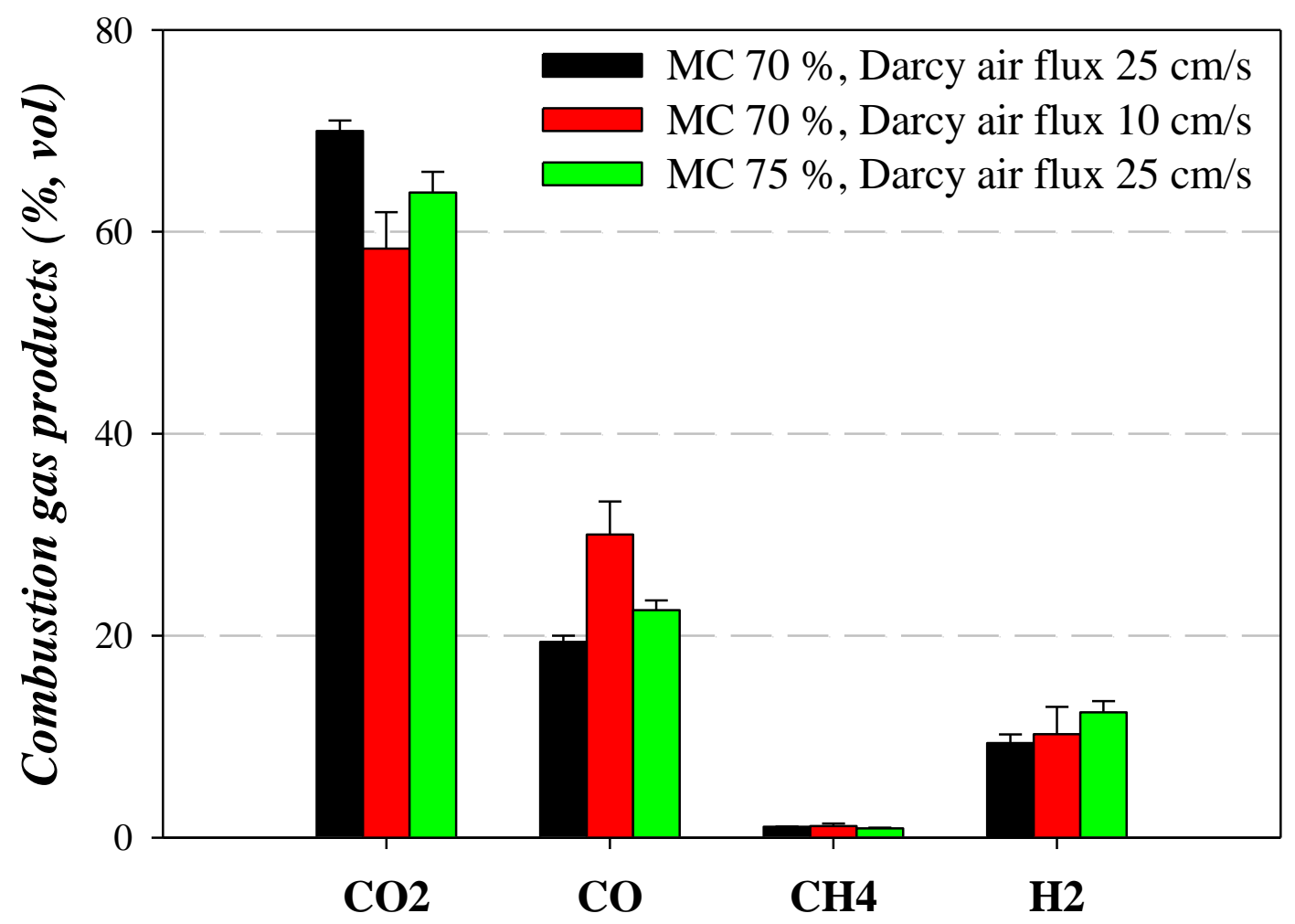

2 
Figure 5.

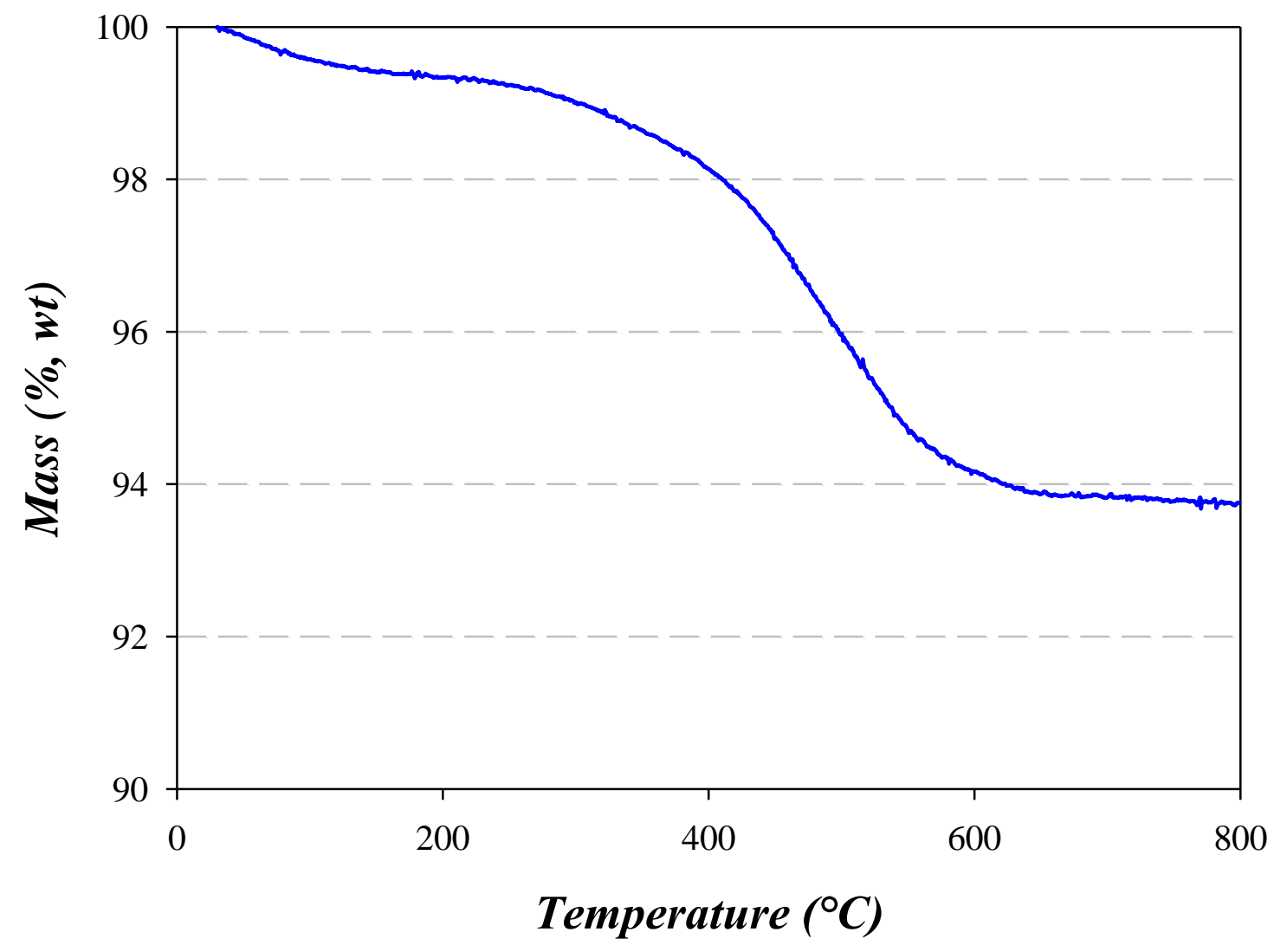

3 
1 Table 1. Thermochemical characterization of used substrates.

\begin{tabular}{|c|c|c|c|}
\hline & & Digestate & Coir \\
\hline Moisture content & Total weight (\%) & $94.8 \pm 0.1$ & $69.7 \pm 0.9$ \\
\hline Volatile solids & Dry basis (\%) & $73.1 \pm 1.9$ & $65.0 \pm 4.0$ \\
\hline Fixed carbon & Dry basis (\%) & $9.6 \pm 1.9$ & $21.8 \pm 0.7$ \\
\hline Ashes & Dry basis $(\%)$ & $17.3 \pm 1.9$ & $13.2 \pm 1.3$ \\
\hline Higher heating value & $\mathrm{kJ} / \mathrm{g}$ & $20.34 \pm 0.13$ & $19.44 \pm 0.23$ \\
\hline \multicolumn{4}{|l|}{ Elemental analysis } \\
\hline $\mathrm{C}$ & & $43.5 \pm 0.3$ & $45.8 \pm 0.8$ \\
\hline $\mathrm{N}$ & & $9.6 \pm 0.1$ & $3.6 \pm 0.2$ \\
\hline S & & $2.7 \pm 0.1$ & $0.5 \pm 0.1$ \\
\hline $\mathrm{P}$ & & $0.8 \pm 0.1$ & $0.4 \pm 0.1$ \\
\hline $\mathrm{Ca}$ & Total weight (\%) & $0.3 \pm 0.1$ & $1.0 \pm 0.1$ \\
\hline $\mathrm{Fe}$ & & $3.8 \pm 0.1$ & $0.2 \pm 0.1$ \\
\hline K & & $1.0 \pm 0.1$ & $0.6 \pm 0.1$ \\
\hline $\mathrm{Mg}$ & & $0.2 \pm 0.1$ & $0.3 \pm 0.1$ \\
\hline $\mathrm{Na}$ & & $0.8 \pm 0.1$ & $0.2 \pm 0.1$ \\
\hline $\mathrm{Zn}$ & & $2465 \pm 72$ & $106 \pm 3$ \\
\hline $\mathrm{Al}$ & & $346 \pm 33$ & $515 \pm 35$ \\
\hline $\mathrm{Cu}$ & $\mathrm{mg} / \mathrm{kg}$ & $51 \pm 3$ & $81 \pm 5$ \\
\hline B & & $35 \pm 3$ & $25 \pm 2$ \\
\hline $\mathrm{Mn}$ & & $33 \pm 3$ & $55 \pm 4$ \\
\hline
\end{tabular}


1 Table 2. Experiments' conditions. Substrate is defined as digestate + coir. The digestate/coir

2 mass ratio defines the moisture content of the waste mixture showed in the second column.

\begin{tabular}{lllll}
\hline Exp & MC (\%)* & $\begin{array}{l}\text { Digestate/Coir } \\
(\mathrm{g} / \mathrm{g})^{\$}\end{array}$ & $\begin{array}{l}\text { Sand/substrate } \\
(\mathrm{g} / \mathrm{g})^{\$}\end{array}$ & $\begin{array}{l}\text { Darcy air flux } \\
(\mathrm{cm} / \mathrm{s})^{\#}\end{array}$
\end{tabular}

\begin{tabular}{|c|c|c|c|c|}
\hline 1 & 70 & 0 & 0 & 5 \\
\hline 2 & 70 & 0 & 0 & 10 \\
\hline 3 & 75 & 0.25 & 0 & 10 \\
\hline 4 & 75 & 0.25 & 0 & 15 \\
\hline 5 & 75 & 0.25 & 0 & 20 \\
\hline 6 & 75 & 0.25 & 0 & 25 \\
\hline 7 & 75 & 0.25 & 0 & 30 \\
\hline 8 & 77 & 0.40 & 0 & 20 \\
\hline 9 & 77 & 0.40 & 0 & 25 \\
\hline 10 & 80 & 0.67 & 0 & 30 \\
\hline 11 & 80 & 0.67 & 0 & 35 \\
\hline 12 & 80 & 0.67 & 0 & 40 \\
\hline 13 & 82 & 0.92 & 0 & 40 \\
\hline 14 & 82 & 0.92 & 0 & 45 \\
\hline 15 & 82 & 0.92 & 0 & 50 \\
\hline 16 & 85 & 1.5 & 0 & 35 \\
\hline 17 & 85 & 1.5 & 0 & 40 \\
\hline 18 & 85 & 1.5 & 0 & 50 \\
\hline 19 & 75 & 0.25 & 0.25 & 5 \\
\hline 20 & 75 & 0.25 & 0.50 & 5 \\
\hline 21 & 75 & 0.25 & 1 & 5 \\
\hline 22 & 85 & 1.5 & 0.25 & 50 \\
\hline 23 & 85 & 1.5 & 0.50 & 50 \\
\hline 24 & 85 & 1.5 & 1 & 50 \\
\hline
\end{tabular}


1 Table 3. Combustion parameters obtained at the different MC and Darcy air flux conditions.

\begin{tabular}{|c|c|c|c|c|c|}
\hline Exp & $\operatorname{MC}(\%)^{*}$ & $\begin{array}{l}\text { Darcy air flux } \\
(\mathrm{cm} / \mathrm{s})^{\#}\end{array}$ & $\begin{array}{l}\mathbf{T}_{\max } \\
\left({ }^{\circ} \mathrm{C}\right)\end{array}$ & $\begin{array}{l}\text { SDR } \\
\left(\mathrm{kg} /\left(\mathbf{h} \cdot \mathrm{m}^{2}\right)\right)\end{array}$ & $\begin{array}{l}\text { DDR } \\
\left(\mathrm{kg} /\left(\mathbf{h} \cdot \mathbf{m}^{2}\right)\right)\end{array}$ \\
\hline 1 & 70 & 5 & $599 \pm 14$ & NSSS & - \\
\hline 2 & 70 & 10 & $865 \pm 20$ & $79.9 \pm 0.1$ & - \\
\hline 3 & 75 & 10 & $770 \pm 18$ & NSSS & - \\
\hline 4 & 75 & 15 & $956 \pm 22$ & $80.9 \pm 0.1$ & $16.2 \pm 0.2$ \\
\hline 5 & 75 & 20 & $867 \pm 20$ & $123.6 \pm 0.2$ & $24.7 \pm 0.2$ \\
\hline 6 & 75 & 25 & $866 \pm 20$ & $123.6 \pm 0.2$ & $24.7 \pm 0.2$ \\
\hline 7 & 75 & 30 & $731 \pm 17$ & $191.0 \pm 0.3$ & $38.2 \pm 0.4$ \\
\hline 8 & 77 & 20 & $742 \pm 17$ & NSSS & - \\
\hline 9 & 77 & 25 & $847 \pm 20$ & $126.1 \pm 0.2$ & $75.7 \pm 0.3$ \\
\hline 10 & 80 & 30 & $727 \pm 17$ & NSSS & - \\
\hline 11 & 80 & 35 & $815 \pm 19$ & $119.0 \pm 0.2$ & $47.6 \pm 0.2$ \\
\hline 12 & 80 & 40 & $888 \pm 21$ & $133.1 \pm 0.2$ & $53.2 \pm 0.3$ \\
\hline 13 & 82 & 40 & $602 \pm 14$ & NSSS & - \\
\hline 14 & 82 & 45 & $712 \pm 17$ & NSSS & - \\
\hline 15 & 82 & 50 & $839 \pm 20$ & $134.1 \pm 0.3$ & $64.4 \pm 0.2$ \\
\hline 16 & 85 & 35 & $512 \pm 12$ & NSSS & - \\
\hline 17 & 85 & 40 & $676 \pm 16$ & NSSS & - \\
\hline 18 & 85 & 50 & $867 \pm 20$ & NSSS & - \\
\hline
\end{tabular}


1 Table 4. Combustion parameters obtained at the different MC, Darcy air flux conditions and 2 sand-to-substrate ratio.

\begin{tabular}{|c|c|c|c|c|c|c|}
\hline $\operatorname{Exp}$ & $\begin{array}{l}\text { MC } \\
(\%) *\end{array}$ & $\begin{array}{l}\text { Darcy air } \\
\text { flux }(\mathrm{cm} / \mathrm{s}) \#\end{array}$ & $\begin{array}{l}\text { Sand/substrate } \\
(\mathrm{g} / \mathrm{g})^{\$}\end{array}$ & $\begin{array}{l}\mathbf{T}_{\max } \\
\left({ }^{\circ} \mathbf{C}\right)\end{array}$ & $\begin{array}{l}\text { SDR } \\
\left(\mathrm{kg} /\left(\mathbf{h} \cdot \mathrm{m}^{2}\right)\right)\end{array}$ & $\begin{array}{l}\text { DDR } \\
\left(\mathrm{kg} /\left(\mathrm{h} \cdot \mathrm{m}^{2}\right)\right)\end{array}$ \\
\hline 19 & 75 & 5 & 0.25 & $\begin{array}{l}1002 \pm \\
24\end{array}$ & NSSS & - \\
\hline 20 & 75 & 5 & 0.50 & $\begin{array}{l}1018 \pm \\
26\end{array}$ & $80.9 \pm 0.3$ & $16.2 \pm 0.3$ \\
\hline 21 & 75 & 5 & 1.00 & $822 \pm 20$ & $84.7 \pm 0.3$ & $16.9 \pm 0.3$ \\
\hline 22 & 85 & 50 & 0.25 & $504 \pm 15$ & NSSS & - \\
\hline 23 & 85 & 50 & 0.50 & $742 \pm 20$ & NSSS & - \\
\hline 24 & 85 & 50 & 1.00 & $750 \pm 18$ & $160.2 \pm 0.4$ & $48.1 \pm 0.4$ \\
\hline
\end{tabular}


1 Table 5. Trace element composition (in $\mathrm{mg} / \mathrm{kg}$ ) of the ashes obtained after smouldering 2 combustion.

\begin{tabular}{|c|c|c|c|}
\hline Trace element & $\mathrm{mg} / \mathrm{kg}$ & Trace element & $\mathrm{mg} / \mathrm{kg}$ \\
\hline $\mathrm{Al}$ & $<$ D.L. & $\mathrm{Mg}$ & $30.3 \pm 0.1$ \\
\hline As & $<$ D.L. & Mn & $0.56 \pm 0.02$ \\
\hline B & $0.49 \pm 0.01$ & Mo & $0.02 \pm 0.01$ \\
\hline $\mathrm{Ba}$ & $<$ D.L. & $\mathrm{Na}$ & $5.07 \pm 0.06$ \\
\hline $\mathrm{Ca}$ & $20.9 \pm 0.4$ & $\mathrm{Ni}$ & $<$ D.L. \\
\hline $\mathrm{Cd}$ & < D.L. & $\mathrm{P}$ & $58.2 \pm 0.8$ \\
\hline Co & < D.L. & $\mathrm{Pb}$ & < D.L. \\
\hline $\mathrm{Cr}$ & < D.L. & S & $1.6 \pm 1.4$ \\
\hline $\mathrm{Cu}$ & $0.02 \pm 0.01$ & $\mathrm{Se}$ & $<$ D.L. \\
\hline $\mathrm{K}$ & $107 \pm 1$ & $\mathrm{Zn}$ & $0.06 \pm 0.04$ \\
\hline
\end{tabular}

